\title{
Is debating primarily a game?
}

\section{William Hawley Davis}

To cite this article: William Hawley Davis (1916) Is debating primarily a game?, Quarterly Journal of Speech, 2:2, 171-179, DOI: 10.1080/00335631609360535

To link to this article: http://dx.doi.org/10.1080/00335631609360535

曲 Published online: 05 Jun 2009.

Submit your article to this journal $\pi$

III Article views: 11

Q View related articles $ᄃ$ 
IS DEBATING PRIMARILY A GAME?

\author{
WILLIAM HAWLEY DAVIS \\ Bowdoin College
}

DEATING is under fire. In many quarters it stands convicted upon Colonel Roosevelt's charge that it cultivates insincerity. Reasonably or otherwise, it is believed in other quarters that it discourages holding and expressing first-hand opinions. A colleague of mine finds debates artificial and unreasonable, and suggests a legislative hearing as a model for intercollegiate speaking contests. No sane man, except perhaps some "expert in debating," can long listen with indulgence or equanimity to the crass assumption of conclusiveness, the flippant repartee, and the obtrusive display of technicality in the use of such words as "colleague," "preceding speaker," "our opponents," "our plan," etc., which debating so often develops. A certain specious argument, one which gave rise temporarily to a vast amount of discussion but which receded into insignificance the more one considered it, has been characterized as "a debater's argument." Is there anyone really acquainted with debating as it is ordinarily practiced who can deny the justice of the appellation?

And it is imprudent to ignore these strictures. For, besides the fact that to many of us debating means bread and butter, the forbearance and the respect of our colleagues and the approval of people in general are things which, within limits, we do well to court. Or, to look at the situation positively, debating is probably, next to athletics, the most widely practiced educational exercise in the country. Virtually all the colleges in the land, so tar as I can learn, and surely also a very large proportion of the secondary schools and academies, indulge in one or more annual debates. Granted that the effect of all this is not really pernicious, as some maintain that it is, is the effect as beneficial as it might be? And

I Read at the third annual meeting of the New England Oral English and Public Speaking Conference, Cambridge, Massachusetts, April 7-8, 1916. 
is there not a responsibility resting upon the acknowledged leaders in this activity, the colleges (without conceit be it stated), to regard it, whenever possible, as an improvable, not a finished, product?

Debating seems to me most in need of readjustment with regard to its aims, its ideals. I find a parallel to the debating situation in the change which has taken place concerning rifle shooting. Target practice indulged in for its own sake seems wasteful and absurd. It is not commendable as a form of exercise. It involves an appalling waste of lead and gunpowder. It encourages after all but a narrow sort of manliness. It seems probable, moreover, that it warps both shoulder muscles and eye muscles. And unquestionably in many instances it facilitates the commission of crime. Target shooting for sport is a sordid if not a pernicious thing.

But consider it as a preparation for national defense. It then becomes a means of training worthy heirs of Robin Hood and Leatherstocking, of Wilhelm Tell, of one's grandfather who helped at the Battle of Grettysburg, and of the whole order of democratic heroes. If we were now the nation of riflemen that we once were, we should not be so panic-stricken when we consider the dangers of foreign invasion. Target shooting from this different angle, with this different purpose or ideal, becomes a different affair.

I am confident also that in the light of that ideal it would become a different target shooting as well. Changing the ideal will change also the thing itself. But upon that aspect I shall not now enlarge.

Let us apply the parallel to debating. If my analysis is correct, two fairly distinct conceptions of debating are recognizable. According to the first of these conceptions debating is a game; the contests in debating exist in and for themselves and are conducted accordingly.

This conception is conspicuously and ably presented in our national organ, the Quarterly Journal of Public Speaking, by its editor, Professor J. M. O'Neill, of the University of Wisconsin. "Contest debating," according to Professor O'Neill, has for its object the disclosure of "better debaters," the "better debating team." Judges of such contests should be able to distinguish "real debating." He says: 
The object of any particular team is to demonstrate its superiority over its opponent in debating. .... Does anyone think for a minute that the object of the Harvard debating team in going to Princeton to debate is not to show, if possible, its superiority in this activity, but is actually to convert the Princetonians to the economic truth expressed by the Harvard side of the question? Of course not.

Again, the following sentences appear above Professor O'Neill's initials in a book review:

It [the book] contains some very thoughtless remarks about the purpose of debating being "to get at the facts," to find the "truth," and not to "beat the other side" or to win a victory. .... The book abounds in inconsistencies. ... In one place debating is depicted as "the most manly of all sports, and a royal sport it is" (preface), and, in another, boys are exhorted to "Go to it, but go to it as a real thing, a thing worth while and not a mere game.",

And Professor O'Neill deplores a system which will allow "industrious and brilliant affirmatives," even when advocating a "hopeless case," to be defeated by "dull and lazy negatives."3

The opposite conception of debating, which I find myself compelled humbly but insistently to advocate, is that of training for the wise disposition of important matters in legislatures, public gatherings, club and society meetings-wherever men collect, as they must constantly be doing, at least in a democracy, for counsel and effective action. Debating, according to this conception, is an approximation of actual conditions, of "real life." The "contest" feature, the "sport" element, while still present, becomes secondary; and superiority, skill, becomes inconceivable apart from the total persuasive effect secured by the contestants. Keeping this conception always in mind controls and modifies the practice of debating itself; it will tend to render futile brilliancy and industry, however great, when employed in advocating falsehood.

I have called these conceptions fairly distinct. The conception of debating as primarily a game, I am confident, prevails nowhere absolutely. No debating team disregards entirely the "search-for-truth" aspect of its work. Nor, on the other hand, has any intercollegiate debating contest been arranged which

I The Quarterly for July, I9I5, p. 204.

${ }^{2}$ See the Quarterly for January, 1916, p. 100.

${ }^{3}$ The Quarterly for July, I915, pp. 202-3. 
eliminates the game aspect entirely and makes the advocacy of the two sides perfectly genuine and the conclusion reached operative and final. Something of each conception must color and modify the other. The emphasis, the chief tendency, the predominating element, nevertheless, belongs to either the one aspect or the other. And it is the transforming and regulating effect of the predominant element which seems to me so important. It is worth while to examine the contrasting effects of the "game" and the "real thing" conceptions when separately allowed to hold sway.

Some preliminary considerations first occur to me. I am cautious about accepting as final the conception of debating as a game, because games are notoriously ephemeral in their nature. Nursery games, it is true, endure. But men's games change and rapidly succeed each other; it is now corner-ball, now baseball, now golf or tennis; and debating is not a nursery game. Debating, as I know it, is about twenty-five years old, and I like to think that if I wish to do so I can secure a living through my connection with it for at least twenty-five years more; if debating is a game $\mathbb{I}$ must begin at once assiduously to cultivate my avocations.

Furthermore, I do not like to think that I occupy my modest academic position merely as an adjunct to sport. The coaches and other sporting instructors $\mathbb{I}$ have known have for the most part been estimable gentlemen, but none of them except a broken-down pugilist whom.I used to see about the Hemenway Gymnasium seemed to be in the work for life; and I am in the work of teaching debating not only for a living but for life. The college which employs me places its director of physical education on its faculty, but not its different coaches and athletic instructors; if I correspond to the latter, and if $\mathbb{I}$ am enjoying a necessary or a gracious exception to the rule, I want to know it and to resign. Understand that I have nothing against paid instructors in special fields of sport, nor against those who like that sort of occupation. I simply haven't classed myself in that group and I do not care to belong to it. If in establishing courses in debating and encouraging debate contests our colleges have simply been indulging the sporting instinct, I have been grossly deceived. The conception of debating 
as a game existing in and for itself drives me to these absurd conclusions.

Of course $\mathbb{I}$ have a faint and almost unnamable suspicion that debating is far more than a sport, that even when blindly and haltingly engaged in its total effect is other than a sporting effect, that as a game it grows ever less significant, that skilfully prosecuted on its other side it would become of infinitely greater effectiveness for practical affairs than it is becoming. But this suspicion I am inclined to discount and to suppress.

One thing is certain: that, frankly accepted as a game, debating becomes a monstrous affair. A game is engaged in for fun; practices clearly improper in dealing with serious affairs, actual conditions, become permissible and even important in the realm of sport; they are "part of the game." And although poker tactics in the game of auction and "talking it up" in baseball seem to most of us improper, none of us can deny that the tricks and deceptions. incident to tennis, baseball, and football are part and parcel of those noble games. Where shall the strategy of the debater begin or end if debating is primarily a game? The erection of specious structures of argument can hardly be ruled out; the more cunningly specious they are, the more commendable, as the fruit of brilliancy and industry, they become. As participants in a game, debaters may devise artfully misleading arguments or wordings, affirmatives may postpone answerable refutation until negatives have no opportunity to answer, negatives may withhold treatment of an "alternative plan" in order to diminish their opponents" opportunity for refutation, and no one can sensibly find fault; it is all in fun. It is hard to see why minor fabrications may not be regarded as venial. Surely the whole nauseating machinery of "colleagues," "opponents," "previous speaker," "next speaker," "we of the negative," "the gentlemen of the affirmative," becomes justified and essential and each debate will be a wordy quarrel between individuals restricted only by their having to speak within time limits and but one at a time.

With debating once established as primarily a game, its purpose being solely to determine "superiority in debating" as apart from converting to truth, technical and elaborate strategy will develop. 
It will be our function as instructors to develop it. We shall have arguments and devices standardized and named for noted debaters or coaches-the O'Neill virtual-admission shift, the Davis logical feint, the Stone now-gentlemen-of-the-jury-manner fake; the King's gambit will have its counterpart in the "alternative plan" or the "withheld alternative plan"; we shall study our debating material for opportunities to use the "common-sense device" or the "red-flag wave." And for each in true Haughton fashion we must devise elaborate guards and defences.

In a recent debate a certain argument presented very rapidly by the negative was misunderstood by the affirmative. Both teams in this instance were quite unsophisticated. The affirmative bluntly requested the negative to repeat the argument. The negative did so, thereby using up a considerable portion of its time. And the affirmative promptly and effectively refuted the argument. In commenting upon this incident one who had misunderstood the purpose of the affirmative said that the affirmative, in getting the negative at their own expense to make their argument conspicuous and thus prepare the way for its effective final refutation, had employed a superlatively skilful piece of strategy. With debating considered as a game, we shall have this sort of thing developed into an art, with all the dramatic accompaniment of consistent facial expression and general bearing. Skill, brilliancy, and industry, superiority in research, thinking, and speaking, all will be evoked by the contest; and I can imagine it as being superb fun into the bargain. But will it not be despicable? Would any of us be proud of having a share in producing it?

If $\mathbb{I}$ have enabled you to follow me thus far, $I$ have made this conception of debating as a game seem untenable. Why untenable? Because we recognize that for some reason or other strategy is repulsive, and devices which contribute to the effectiveness and enjoyment of football and tennis and chess are not quite in keeping with debating. We recognize, as it seems to me, that, although debating may not be an ideal method of arriving at truth, the element of truth and the searching for truth are somehow more than accidental and incidental in connection with debating. 
For a long time $\mathbb{I}$ have been trying to discover the reasonable basis for this feeling, to determine why it is that good form, whether it is or is not supplemented by rules or expert directions concerning debating, makes certain kinds of strategy clearly inadmissible and permits others only with cautious reservations. I begin to discern a reason, adequate at least for myself. I am impressed by the reality involved in a debating contest, by the inescapable fact that the debate deals with truth rather than jest, with things and not with playthings. It is the ultimate, not the temporary, element involved in debating which seems to me to make it worth practicing. I find illuminating the second conception of debating which I have attempted to express, the conception of it not as a game but as a counterfeit presentment of a practical, efficient, necessary, and familiar method of dealing with pressing and important affairs.

The situation in any debate seems to me to be tacitly as follows: An organization is convened for the determination of some important matter; it is not routine business, it is vitally important business. A motion is made and seconded, and discussion takes place. There is much to be said on both sides, and each side knows that the motion will pass or fail to pass as a result of the presentation which it makes. The aim of each side is the same-the wise disposition of that motion. Victory in the vote itself is insignificant; the wise and final or permanent decision of the question is all. The function of each side in determining what that decision shall be is the same; for truth establishes itself in these days, not by direct revelation from an unquestioned source, but by hard contest with truth-seeming error. This obliges each side to make the most convincing array of considerations leading to the vote which it favors. Each side is dealing, not with some sphere or oval inflated with wind, but with the great human verities, as nearly as they can be ascertained. A sport, a royal sport indeed, this is, if you will, when considered as a counterfeit presentment; but it is at the same time, and primarily, an effort to get at the truth, and derives value as a counterfeit only in so far as it is in this main purpose faithful to the real, to the original which it counterfeits. 
Devices, strategy, speciousness, according to this conception, are suicidal, human nature being somehow so constituted that resorting to these amounts to a confession of weakness. According to this conception, other things being equal, the "hopeless cases" will never win; and when an erroneous decision on the motion is reached, it will be a comment, not upon the skill of the winners, but upon the gross incompetency of the losers. And each of these results, I maintain, is salutary in its effect.

The distinction between the two ideals is vital. The conception of debating as a mere game places a premium upon mere cleverness, upon argumenta ad homines; upon the ability, when occasion serves, to make the worse appear the better reason. The conception of debating as an artificial but a genuine means of arriving at the just determination of important matters places a premium upon genuineness, integrity, and sincerity.

I have elsewhere endeavored to forecast some of the detailed effects which the subordination of the game element in debating will bring about. Much more might here be said concerning them. But the conception itself is the main thing to be considered. The element of truth and the approximation of reality once accepted as primarily important in debating, little things like the choice of judges and the elimination of petty formality will follow in due course.

And is not this readjustment of our ideals with respect to debating precisely the readjustment which needs to be brought about in our attitude toward legal and political contests in this country? Your tired business man may need to have the game element in his life made more prominent. The people of this country, including the students in the colleges of this country, taken by and large, do not. We are already inclined to regard a criminal trial as a game, and to applaud the cleverness of counsel above the integrity of arguments. What about the third-term argument relative to the presidency to which people gave so much weight a few months ago? Who regards it seriously now? It was a "debater's argument." In the Lincoln-Douglas debates, which principal stressed the game element in the controversy? When debaters in real and

\footnotetext{
I See the Quarterly for July, I9I 5, Pp. IO9-I3.
} 
in mock contests alike reflect consistently the spirit of Lincoln in those debates, when Harvard and Princeton debaters are animated by a genuine desire to convert their hearers to the truth as they see it, the term "debater's argument" will become what it ought to be, a commendatory and an honorable appellation.

I consider it distinctly to the credit of our colleges that they see fit to foster efforts in this direction, for that is what I consider their encouragement of debating to be. I consider a man to be honorably and profitably employed who exerts himself to make young men conduct investigations and enter contests based upon the conception that truth is discoverable and presentable and that it can be made to prevail. I take it that those who most zealously maintain that debating is chiefly a sport act for the most part in their instruction and their coaching upon the other conception. But their declared conception of debating is dangerous and will lead to fatal modifications in their practice. And more and more the game which their conception contemplates will bring upon them and it the ridicule and the infamy which in some quarters is already being justly heaped upon short-sighted debating contests.

Our wavering between these two conceptions of debating has already borne sad fruit. The strategy, the devices to which in our concern for it merely as a sport we have already stooped, have spread among us and among our admiring friends with amazing rapidity. Before we know it the spirit of those devices will be more widely caught and will be given still freer reign. And the leading colleges, and an organization such as this Conference, cannot too promptly begin to revise and improve debating ideals and practices, if this important means of securing effective training in speaking is to be rescued from merely a place in the encyclopedia of ancient and curious games and pastimes, and made what it is capable of being - an enduring and an honorable means of preparing citizens to participate in the work of living and governing, of deciding intelligently and confidently the serious questions which from time to time arise. 